\title{
Effect of Corn Fermented by Saccharomyces cerevisiae in Diets on Production Performance of Broiler Chicks
}

\author{
Ali J. Hammod \\ Department of Animal Resources, Faculty of Agriculture, University of Kufa, Kufa, Iraq.
}

\begin{abstract}
The current study undertaken in the broiler farm belonging to Department of Animal Resources, Faculty of Agriculture, University of Kufa during the period of 13/8/2014 to 17/9/2014 to investigate the effects ofcorn fermented by S.cerevisiae (Saccharomyces cerevisiae) in diets on production performance of broiler chicks. $1 \mathrm{gm}$ of S.cerevisiae per $1 \mathrm{~kg}$ of feed. 121 day of age and unsexed chicks (Ross 308) were used with average weight of $\mathbf{4 0 . 5} \mathbf{g m} /$ chick. Four treatments were used: T1(standard diet contained unfermented corn), T2 (standard diet with contained fermented corn for 6 hr), T3(standard diet with contained fermented corn for $\mathbf{1 2} \mathrm{hr}$ and T4(standard diet contained fermented corn for $\mathbf{2 4} \mathrm{hr}$. Results showed a significant effect $(\mathrm{P} \leq \mathbf{0 . 0 5})$ of $\mathrm{T} 4$ on live body weight, cumulative body gain and economic figure compared with the other treatments. Significant increase in chicks fed on T4 in feed consumption while no significant effect of fermented corn addition on final feed conversion and viability.

Keywords: Feed, yeast, broiler, corn, fermentation.
\end{abstract}

*Correspondence: alij.alhemaidawi@uokufa.edu.iq

(Received: 30 March 2019; accepted: 15 May 2019)

Citation: Ali J. Hammod, Effect of Corn Fermented by Saccharomyces cerevisiae in Diets on Production Performance of Broiler Chicks, J Pure Appl Microbiol., 2019; 13(2): 1025-1030. doi: 10.22207/JPAM.13.2.40

(c) The Author(s) 2019. Open Access. This article is distributed under the terms of the Creative Commons Attribution 4.0 International License which permits unrestricted use, sharing, distribution, and reproduction in any medium, provided you give appropriate credit to the original author(s) and the source, provide a link to the Creative Commons license, and indicate if changes were made. 


\section{INTRODUCTION}

Attenuating the cost of diets and improving the quality of feed are the major aims of all breeders in poultry industry because feed is play crucial role in attainment of profit and constitute about of $60-70 \%$ from production cost ${ }^{1}$. Corn is one of dominant grain which use usually with high ratio in poultry diets and its constitute about $75 \%$ of poultry diet ${ }^{2}$. Corn contain of $8.5 \%$ protein, $4.3 \%$ ether extract, $2.1 \%$ crude fibers, $3350 \mathrm{kcal} . / \mathrm{kg}^{3}$ and $81 \%$ of digestive coefficient ${ }^{2}$. S.cerevisiae is one of important microbiology which used in microbial fermentation because it high ability of growth and we can control on it easily therefore it used widely in production and industrial projects, in addition to the high contain of protein and health safety ${ }^{4}$. Multiple uses of S.cerevisiae in many fields such as bread and glycerol manufacturing and it characterized of not produce the toxins, it also play an important role in enzymes production such as glucose 6 phosphate dehydrogenase $\mathrm{e}^{5,6}$. S.cerevisiae used for decreasing of aflatoxins poisons $\mathrm{s}^{7,8,9}$.

The major aim of this study is to determine the effect of fermented corn with S.cerevisiae on broiler to raise the efficiency of feed and decrease the cost of production.

\section{MATERIALS AND METHOD Corn fermentation}

After the corn grinding to a suitable volume, it's weighted and backed inside bags made of polyethylene and moisturized by water to $50 \%$ and the add the S.cerevisiae which obtained from local market. S.cerevisiae which used in this experiment was a Turkish origin manufactured from saf-instant company. Mixing ratio between corn and yeast was $1 \mathrm{gm} / \mathrm{Kg}$. After mixing, the mixture was put in the bags, closed tightly and stored in room under $25-30^{\circ} \mathrm{C}$ for three periods 6,12 and 24 hours according to Shalesh et al. ${ }^{9}$. The growing of yeast is beginning from 0 hour and reach to the maximum growth at 24 hours. Finally, the mixture bags opened and the mixtures was dried on clean floor and added to the diets.

\section{Farm experiment}

The farm experiment was conducted in poultry farm belonging to University of Kufa, Faculty of Agriculture during the period of $13 / 8 / 2014$ to $14 / 9 / 2014$ to determine the effect of corn fermented by S.cerevisiae in diets on production performance of broiler chicks.

\section{Feeding}

Chicks were fed on starter ration for three weeks of age followed by finisher ration until the $5^{\text {th }}$ week of age and the treatments were: $\mathrm{T} 1$ (standard diet, contained of corn-unfermented), T2 (contained of corn fermented by S.cerevisiae for $6 \mathrm{hr}$.), T3(contained of corn fermented by S.cerevisiae for $12 \mathrm{hr}$.) and T4 (contained of corn fermented by S.cerevisiae for $24 \mathrm{hr}$.

\section{Management}

120 chicks (class Ross 308 ) at $1^{\text {st }}$ day of

Table 1. Gross composition and calculated analyses of the experimental diets

\begin{tabular}{|c|c|c|}
\hline \multirow[b]{2}{*}{ Ingredients } & \multicolumn{2}{|c|}{ Diets } \\
\hline & $\begin{array}{l}\text { Starter } \\
\%\end{array}$ & $\begin{array}{c}\text { Finisher } \\
\%\end{array}$ \\
\hline Ground maize & 30 & 31 \\
\hline Wheat & 30 & 31 \\
\hline $\begin{array}{l}\text { Soybean meal } \\
(44 \% \text { CP })\end{array}$ & 31 & 34.75 \\
\hline Sunflower oil & 1.25 & 3.5 \\
\hline Premix $^{1}$ & 3 & 2.5 \\
\hline $\begin{array}{l}\text { Dicalcium } \\
\text { phosphate }\end{array}$ & 0.7 & 0.7 \\
\hline Salt & 0.3 & 0.3 \\
\hline Total & 100 & 100 \\
\hline \multicolumn{3}{|c|}{ Calculated composition } \\
\hline Crude protein\% & 22.98 & 21.32 \\
\hline $\begin{array}{l}\text { Metabolizable } \\
\text { energy (Kcal/kg) }\end{array}$ & 2981.4 & 3138.8 \\
\hline Energy: Protein & 129 & 147 \\
\hline Crude fiber \% & 3.02 & 3.14 \\
\hline Crude fat $\%$ & 2.51 & 3.22 \\
\hline Calcium \% & 1.01 & 0.99 \\
\hline Avi. Phosphorus\% & 0.48 & 0.46 \\
\hline
\end{tabular}

(1) Use of Premix Jordanian Origin Type Provimi 3110 Contains: $2750 \mathrm{kcal} / \mathrm{kg}$ Representative energy, $10 \%$ raw protein, $1.1 \%$ fat, $21 \%$ calcium, $11.0 \%$ phosphorus, $6.5 \%$ methionine, $6.5 \%$ methionine + Lysine, $4.8 \%$ Sodium, $5.4 \%$ Chloride, $575000 \mathrm{IU}$ Vitamin A, 201250 IU Vitamin D3, $1380 \mathrm{mg}$ Vitamin E, $138 \mathrm{mg}$ Vitamin K3, $138 \mathrm{mg}$ Vitamin B1, $345 \mathrm{mg}$ Vitamin B, $1840 \mathrm{mg}$ Vitamin B3, $552 \mathrm{mg}$ Vitamin 5 B, $184 \mathrm{mg}$ B vitamins, $46 \mathrm{mg}$ vitamin $B 9,1000$ micrograms $B 12,6900$ micrograms peyutin, $14,000 \mathrm{mg}$ choline chloride, $460 \mathrm{mg}$ copper, $2760 \mathrm{mg}$ iron, $3680 \mathrm{mg}$ manganese, $3680 \mathrm{mg}$ zinc, $50 \mathrm{mg}$ iodine, $9.2 \mathrm{mg}$ selenium, $30000 \mathrm{~m}$ Vitez mine, $250 \mathrm{mg}$ antioxidants, $250 \mathrm{mg}$ lincomycin, $2400 \mathrm{mg}$ selenomycin). 
age and unsexed with $40.5 \mathrm{gm}$ of average weight were used and reared in closed enclosure divided of pens $\left(3 \mathrm{~m}^{2} /\right.$ pen) and chicks distributed randomly inside pens. All the necessary equipments were found to achieve the optimal temperature during the rearing period and sawdust ( $7 \mathrm{~cm}$ of thickness) while water and feed were supplemented $A d$ libitum. Chicks were fed the experimental diets from 1-35 days of age Table 1.

Weekly live body weight, weekly and cumulative body weight gain, total and weekly feed consumption, total mean, economic figure and livability ratio were calculated ${ }^{11}$. Data were analyzed by completely randomized design (C.R.D.) according to computer statistical program ${ }^{12}$ while significance of means differences was tested by Duncan multiple range test ${ }^{13}$.

\section{RESULTS AND DISCUSSION}

Results represented in Table 2 showed no significant effect of diets that contained corn fermented by S.cerevisiae on weekly live body weight in $1^{\text {st }}, 2^{\text {nd }}$ and $3^{\text {rd }}$ week of age while the T4 effected significantly $(P \leq 0.05) A T 4^{\text {th }}$ week of age (1185 gm). The highest body weight in last week was in T4, it's about 1504 gm with a significant difference with $\mathrm{T} 1$ and $\mathrm{T} 2$ but no significant difference with T3. Results showed a clear difference among treatments resulted from the elongation of fermentation time which lead to increase of yeast growth through increasing of biomass especially the enzymes content which necessary in digestion process. In addition, yeast consider as probiotic to displace the harmful pathogens outside the digestive system, the results are similar with the results of El Barkouky et al. ${ }^{14}$ when he used $3 \mathrm{gm}$ of yeast/ $\mathrm{kg}$ of feed to the diets of broiler males and noticed a significant enhancement in final body weight compared with control.

Results represented in table 3 showed no significant effect of fermented diets in both $1^{\text {st }}$ and $2^{\text {nd }}$ week of age compared with control. The highest significant effect $(P \leq 0.05)$ was found in T4

Table 2. Effect of fermented maize by S.cerevisiae in diets on the live body weight (g) of broiler chicks for 5 weeks.

\begin{tabular}{|c|c|c|c|c|c|}
\hline \multirow[b]{2}{*}{ Treatments } & \multicolumn{5}{|c|}{ Age/week } \\
\hline & 1 & 2 & 3 & 4 & 5 \\
\hline $\mathrm{T} 1$ & $170 \pm 1$ & $379 \pm 12.0$ & $682 \pm 37.0$ & $\begin{array}{c}1072 \pm 2.5 \\
\text { bc }\end{array}$ & $\begin{array}{c}1309 \pm 5.5 \\
b\end{array}$ \\
\hline $\mathrm{T} 2$ & $177 \pm 2.5$ & $390 \pm 11.5$ & $665 \pm 23.0$ & $\begin{array}{c}1020 \pm 30.0 \\
c\end{array}$ & $\begin{array}{c}1328 \pm 21.0 \\
b\end{array}$ \\
\hline T3 & $168 \pm 3.0$ & $368 \pm 26.0$ & $735 \pm 14.0$ & $\begin{array}{c}1105 \pm 25.0 \\
b\end{array}$ & $\begin{array}{c}1480 \pm 23.0 \\
a b\end{array}$ \\
\hline T4 & $176 \pm 3.5$ & $374 \pm 88.0$ & $743 \pm 6.5$ & $\begin{array}{c}1185 \pm 15.0 \\
a\end{array}$ & $\begin{array}{c}1504 \pm 36.0 \\
a\end{array}$ \\
\hline
\end{tabular}

T1: standard diet, T2: contained of corn fermented by S. cerevisiae for 6 hr., T3: contained of corn fermented by S. cerevisiae for $12 \mathrm{hr}$. and T4: contained of corn fermented by S. cerevisiae for $24 \mathrm{hr}$.

during $3^{\text {rd }}$ and $4^{\text {th }}$ week of age, it's about $375 \mathrm{gm}$ compared with control which was about $237 \mathrm{gm}$ while no significant difference between $\mathrm{T} 2$ and $\mathrm{T} 4$.

Due to cumulative body gain, results showed a significant increase in T4 compared with $\mathrm{T} 1$ and $\mathrm{T} 2$ while no significant difference between $\mathrm{T} 1$ and $\mathrm{T} 2$ or between $\mathrm{T} 3$ and $\mathrm{T} 4$, this resulted from the increase of the fermentation period of corn and the decrease of accumulative body gain in $5^{\text {th }}$ week may be resulted from the high temperature inside the rearing farm compared with the optimal level.
Results in Table 4 showed that no significant effect of fermented corn on weekly and total accumulative feed consumption in $1^{\text {st }}$ and $2^{\text {nd }}$ week of age while the highest significant increase in weekly or accumulative feed consumption was noticed in T4 in the $5^{\text {th }}$ week of age. No significant differences between $\mathrm{T} 1$ and $\mathrm{T} 2$ in both weekly or accumulative feed consumption for all ages. Depending on the results of the current study we can expect to reasons for increasing the feed consumption in T4, first reasons is the enhancement of Palatability of feed after yeast 
Table 3. Effect of fermented maize by S. cerevisiae in diets on the weight gain (g) of broiler chicks for 5 weeks.

\begin{tabular}{|c|c|c|c|c|c|c|}
\hline \multirow[b]{2}{*}{ Treatments } & \multicolumn{6}{|c|}{ Age/week } \\
\hline & 1 & 2 & 3 & 4 & 5 & $0-5$ \\
\hline $\mathrm{T} 1$ & $129 \pm 1.5$ & $209 \pm 10.5$ & $\begin{array}{c}303 \pm 25.5 \\
a b\end{array}$ & $\begin{array}{c}390 \pm 40.0 \\
a b\end{array}$ & $\begin{array}{c}237 \pm 3.0 \\
b\end{array}$ & $\begin{array}{c}1268 \pm 5.5 \\
b\end{array}$ \\
\hline $\mathrm{T} 2$ & $136 \pm 2.5$ & $213 \pm 9.0$ & $\begin{array}{c}275 \pm 12.0 \\
b\end{array}$ & $\begin{array}{c}355 \pm 53.5 \\
b\end{array}$ & $\begin{array}{c}308 \pm 8.5 \\
a b\end{array}$ & $\begin{array}{c}1287 \pm 21.5 \\
\text { b }\end{array}$ \\
\hline T3 & $127 \pm 3.0$ & $200 \pm 23.0$ & $\begin{array}{c}367 \pm 12.0 \\
a\end{array}$ & $\begin{array}{c}370 \pm 39.0 \\
b\end{array}$ & $\begin{array}{c}375 \pm 15.0 \\
a\end{array}$ & $\begin{array}{c}1439 \pm 30.0 \\
a b\end{array}$ \\
\hline T4 & $135 \pm 3.5$ & $198 \pm 11.0$ & $\begin{array}{c}369 \pm 18.0 \\
a\end{array}$ & $\begin{array}{c}442 \pm 30.5 \\
a\end{array}$ & $\begin{array}{c}319 \pm 14.0 \\
a b\end{array}$ & $\begin{array}{c}1463 \pm 21.5 \\
a\end{array}$ \\
\hline
\end{tabular}

T1: standard diet, T2: contained of corn fermented by S. cerevisiae for $6 \mathrm{hr}$., T3: contained of corn fermented by S. cerevisiae for $12 \mathrm{hr}$. and T4: contained of corn fermented by S. cerevisiae for $24 \mathrm{hr}$.

addition. Second reason, the increase of feed consumption resulted from the increase of body weight as the age advance which lead to increase the body capacity of corn contain the yeast. The results are similar with the results that reported from Al-Mosawi et al. ${ }^{15}$ who noticed a significant effect on feed consumption when he used 1.5 and $2.25 \%$ of S.cerevisiae in broiler diets.
Results in Table 5 showed no significant effect of fermented corn on feed conversion coefficient in all periods and for all ages, the results came accordance with the results of Hammod ${ }^{16}$ who proved no significant effect of different levels of fermented wheat on feed conversion coefficient.

Table 4. Effect of fermented maize by S.cerevisiae in diets on broiler feed intake (g) for 5 weeks.

\begin{tabular}{lcccccc}
\hline & \multicolumn{5}{c}{ Age/ weeks } \\
\cline { 2 - 7 } Treatments & 1 & 2 & 3 & 4 & 5 & $0-5$ \\
\hline T1 & $137 \pm 2.0$ & $350 \pm 6.0$ & $596 \pm 8.5$ & $997 \pm 7.0$ & $1167 \pm 57.0$ & $3247 \pm 49.0$ \\
& & & $b$ & $b$ & $b$ & $b$ \\
T21 & $39 \pm 2.0$ & $366 \pm 4.0$ & $527 \pm 8.0$ & $1077 \pm 23.0$ & $1225 \pm 25.0$ & $3334 \pm 42.0$ \\
& & & $b$ & $b$ & $a b$ & $b$ \\
T3 & $137 \pm 2.5$ & $342 \pm 18.0$ & $637 \pm 17.5$ & $1031 \pm 38.0$ & $1297 \pm 17.5$ & $3444 \pm 18.0$ \\
& & & $a$ & $b$ & $a b$ & $b$ \\
T4 & $143 \pm 3.0$ & $376 \pm 3.5$ & $627 \pm 13.0$ & $1177 \pm 18.0$ & $1362 \pm 22.0$ & $3685 \pm 32.0$ \\
& & & $a$ & $a$ & $a$ & $a$ \\
\hline
\end{tabular}

T1: standard diet, T2: contained of corn fermented by S. cerevisiae for 6 hr., T3: contained of corn fermented by S. cerevisiae for $12 \mathrm{hr}$. and T4: contained of corn fermented by S. cerevisiae for $24 \mathrm{hr}$.

Results in Table 6 showed no significant effect of experimental treatments on viability, the results similar with the results of Onwurah ${ }^{17}$ who reported that viability did not affected by fermented diets by S.cerevisiae in different levels $0.5,1.0,1.5$ and $2.0 \mathrm{gm} / \mathrm{kg}$ of feed or gm/ liter of drinking water or both. The results in Table 6 showed a significant increase $(P \leq 0.05)$ of economic figure in T4 compared with $\mathrm{T} 1$ and $\mathrm{T} 2$ while no significant deference between $\mathrm{T} 1$ and $\mathrm{T} 2$ or between T3 and T4. The chicks that fed on T4 were the highest of economic figure compared with others groups and that resulted from the increase of body weight which reflex positively on economic figure. 
Table 5. Effect of fermented maize by S.cerevisiae in diets on the feed conversion ratio (feed/gain) of broiler chicks for 5 weeks

\begin{tabular}{lcccccc}
\hline & \multicolumn{5}{c}{ Age/week } \\
\cline { 2 - 7 } Treatments & 1 & 2 & 3 & 4 & 5 & $0-5$ \\
\hline T1 & $1.05 \pm 0.23$ & $1.67 \pm 0.06$ & $1.96 \pm 0.11$ & $2.55 \pm 0.24$ & $4.92 \pm 0.30$ & $2.56 \pm 0.06$ \\
T2 & $1.01 \pm 0.01$ & $1.72 \pm 0.09$ & $1.91 \pm 0.06$ & $3.03 \pm 0.40$ & $3.97 \pm 0.27$ & $2.58 \pm 0.01$ \\
T3 & $1.07 \pm 0.04$ & $1.71 \pm 0.11$ & $1.73 \pm 0.01$ & $2.78 \pm 0.33$ & $3.45 \pm 0.43$ & $2.39 \pm 0.23$ \\
T4 & $1.05 \pm 0.01$ & $1.89 \pm 0.06$ & $1.70 \pm 0.07$ & $2.66 \pm 0.55$ & $4.26 \pm 0.26$ & $2.52 \pm 0.04$ \\
\hline
\end{tabular}

T1: standard diet, T2: contained of corn fermented by S. cerevisiae for $6 \mathrm{hr} ., \mathrm{T} 3$ : contained of corn fermented by S. cerevisiae for $12 \mathrm{hr}$. and T4: contained of corn fermented by S. cerevisiae for $24 \mathrm{hr}$.

Table 6. Effect of fermented maize by S.cerevisiae in diets on viability and economic figure of broiler chicks for $5^{\text {th }}$ week

\begin{tabular}{lcc}
\hline Treatments & $\begin{array}{c}\text { Viability } \\
\%\end{array}$ & $\begin{array}{c}\text { Economic } \\
\text { figure }\end{array}$ \\
\hline T1 & $90 \pm 0.0$ & $\begin{array}{c}136 \pm 5.6 \\
\mathrm{~b}\end{array}$ \\
$\mathrm{~T} 2$ & $97 \pm 5.0$ & $\begin{array}{c}142 \pm 10.0 \\
\mathrm{~b}\end{array}$ \\
$\mathrm{~T} 3$ & $90 \pm 10.0$ & $\begin{array}{c}163 \pm 11.0 \\
\mathrm{ab}\end{array}$ \\
$\mathrm{T} 4$ & $100 \pm 0.00$ & $170 \pm 9.8$ \\
& & $\mathrm{a}$ \\
\hline
\end{tabular}

T1: standard diet, T2: contained of corn fermented by $S$. cerevisiae for $6 \mathrm{hr}$., T3: contained of corn fermented by $S$. cerevisiae for $12 \mathrm{hr}$. and T4: contained of corn fermented by S. cerevisiae for $24 \mathrm{hr}$.

\section{ACKNOWLEDGMENTS}

We would like to thanks Faculty of Agriculture, University of Kufa for allowing me doing this research at its laboratories.

\section{FUNDING}

None.

\section{DATA AVAILABILITY}

All datasets generated or analyzed during this study are included in the manuscript.

\section{ETHICS STATEMENT}

This article does not contain any studies with human participants or animals performed by any of the authors.

\section{REFERENCES}

1. Jerdan K.K. Determine the lower lost of production for chick using different levels of white corn (sorghum) instead of yellow corn (maize) in broiler chickens feed. Kut. J. for Economic Administration Science, 2015; 18: 130-137.

2. Al-Yaseen A.A. and Abdul-Abass M.H. Nutrition of poultry. University of Baghdad. College of Agriculture, Iraq, 2010.

3. National Research Council. Nutrient Requirements of poultry, $9^{\text {th }}$ ed. National Academy Press, Washington, DC., 1994.

4. Kadhum S.W. and Abbas A.B. Study of effciency of Saccharomyces cerevisiae in reducing the toxic effects of aflatoxin B1and B2 in male albino rats. Journal of Al-Qadisiyah for pure science, 2014; 9: 1-8.

5. Al-Soufi M.A.A. Purification, Characterization and Utilization of (G6PD) From Locally Isolated Yeast Saccharomyces cerevisiae. Ph. D. thesis, Collage of Agriculture, University of Baghdad, 2005.

6. AL-mohamedawi S.S.Z. Study Of Invertase Production From A Local Isolate of Saccharomyces cerevisiae. MSc thesis, Collage of Agriculture, University of Basra, 2009.

7. Al-Daraji H.J.; Al-Ani I. A., Minati J.K. and,Mukhlis S.A. Evaluation of the efficacy of liquor ice extract and Saccharomyces cerevisiae to suppress the toxic effects of aflatoxin in broilers. Iraqi J. of Agri. Sci., 2005; 36: 203-210.

8. Naji, S. A.; Al-Ani, I. A.; AL-Dhanqi, Z. T.; Menati, J. K. and Al-Hety H.E., 2007. The effect of using different treatments to suppress the deteriorates effects of aflatoxicosis on broiler performance. Iraqi J. Poultry Sci., 2: 1-16.

9. Yousif A.A. and Al-Jugifi W.E.K. The effect of using eshnan (Seidlitziaros marinus) and some biological treatments to reduce Mycotoxins effect an broiler breeders (Ross 308) progene performance of the descendants. Anbar J. of Agri.Scie., 2015; 13: 112-122.

10. Shalesh F.J., Ali F.R., Frahan S.R., Mahmood S.A. and Mari A.M. Role of magnesium ions on Improvement of Fermentative activity of local yeast isolates Saccharomyces cerevisiae for ethanol production. Journal of Biotechnology Research Center, 2013; 7: 18-26. 
11. Ahmad J. and Sharma J.M. Evaluation of amodifiedlivevirus vaccine administrated in ovo to protect chicken against Newcastle disease. Am.J. Vet.Res., 1992; 53: 1999-2004.

12. SAS. SAS/STAT User's Guide for Personal Computers. Release 7.0 SAS Institute Inc., Cary N.C., USA, 2012.

13. Duncan B.D. Multiple range and multiple F. tests, Biometrics, 1955; 11:1-42.

14. ElBarkouky E.M., Mohamed F.R., Atta A.M., Abu Taleb A.M., ElMenawey M.A. andHatab M.H. Effect of Saccharomyces cerevisiae and vitamin c supplementation on performance of broilers subjected to ochratoxina contamination. Egypt Poult. Sci., 2010; 30: 89-113.
15. Al-Mosawi I.F.B., Hassan M.A., Attalah S. and Jabbar S.K. The effect of diet supplementation with Saccharomyces cerevisiae yeast on broiler performance reared floor and cage rearing systems. Al-Muthanna J. For Agric. Sci., 2013; 1: 136-148.

16. Hammod A.J. Effect of Replaced Partial or Complete Fermented Wheat Instead of Corn on some Productive and Physiological Traits of Broiler Chicks. Ph. D. thesis, Collage of Agriculture, University of Basra, 2016.

17. Onwurah F.B., Amaefule K.U. and Ahamefule F.O. Effect of baker's yeast (Saccharomycescerevisiae) inclusion in feed and in drinking water on performance of broiler birds. British J. Appl Sci. Tech., 2014; 4: 144-151. 